\title{
The Commitment with FDI Firms of Accountants in Noi Bai Industrial Park - Creative Application in Economics Sociological Knowledge
}

\author{
Duc Tai Do \\ Ph.D, University of Labor and Social Affairs, Vietnam \\ Thi Huyen Yen Chu \\ Ph.D, Faculty of Social work, University of Labor and Social Affairs, Vietnam \\ Hong Hanh Ha \\ Ph.D, School of Accounting and Auditing, National Economics University, Vietnam \\ Bich Thuy Vu \\ MA, Faculty of Accounting, Trade Union University, Vietnam
}

\begin{abstract}
s
This study was conducted to identify, evaluate and measure the attributes of accountants' commitment with FDI firms in Noi Bai industrial park, Hanoi based on the organizational commitment theory of Meyer \& Allen (1991) and Creative application in economics sociological knowledge. Beside, we based on literature review and the results of some interviews, 150 questionnaires were sent directly to accountants in FDI firms in Noi Bai industrial park and were collected in 1 month. However, only 110 questionnaires were satisfactory and included in the analysis. The results of descriptive statistics, Cronbach's Alpha analysis and Independent T-test have identified and measured 12 attributes of accountants' commitment which effect on accountants in the FDI firms in Noi Bai industrial park. Based on the findings, some recommendations are given to improve the accountants' commitment.
\end{abstract}

Keywords: commitment, accountants, FDI firms, Noi Bai industrial park

JED codes: M41, M40, O15

DOI: $10.7176 /$ RJFA/10-22-15

Publication date: November $30^{\text {th }} 2019$

\section{Introduction}

Employee commitment is the main key to the organization's success in a competitive environment. When employees commit with the organization, they will perform in their best capacity, contribute to the organization's overall goals. This is exactly what businesses always want to achieve from their employees (Bui, 2018). By recruiting and retaining the best employees, companies can get higher profitability and market share than average (Smith, 207).

Noi Bai Industrial Park was developed by Noi Bai Development Company, a joint venture company between Renon (Malaysia) and Hanoi industrial construction Company, under the Investment License No. 839 / GP which was issued Ministry of Planning and Investment of Vietnam on 12/4/1994. The industrial park has attracted approximately 20 projects, 37 firms, with the total capital of hundred of millions of dollars, the occupancy ratio is $100 \%$. Noi Bai Industrial Park plays a particularly important role in the development of the national economy, which has created opportunities for industrial development and shortened industrialization because it combined and learned from the latest achievements in science and technology. As for organization and management, they took advantage of foreign investment capital for development. In addition, Noi Bai Industrial Park has created job opportunities for thousands of workers, eradicating poverty and developing human resources, etc.

In the global integration era, competition among enterprises becomes fiercer than ever. Recruit talents are hard, but how to retain them is even harder, especially high-quality accounting personnel. In recent years, the situation of leaving the organization for a new workplace is becoming a problem of many organizations and businesses in general and FDI firms in Noi Bai industrial park in particular.

Previous studies have shown that the cost of an employee quitting the job is high, which is counted up to $\$$ 78,000 to find a replacement (Ramsey, 2004). These costs include recruitment, training (Alexander et al., 1994), social costs (Des \& Shaw, 2001), temporary loss of labor productivity (Osterman, 1987) and, more importantly, organizations also lose other hidden knowledge. Therefore, researching the commitment with FDI firms of accountants is appropriate, which has scientific significance and contributes to helping human resource managers in FDI firms to develop the human resource program. 


\section{Literature Review}

Typical studies in the world about organizational commitment such as Commitment with the organization are defined as the strong steadfastly, the consistency of an individual with the organization and active participation in a specific organization (Mowday et al., 1979). Commitment with the organization is defined as the psychological state of a member in the organization, reflecting the extent to which individuals absorb, or accept the characteristics of the organization (O'Reilly \& Chatman, 1986). Mayer \& Allen (1991) defined, committing with an organization as a psychological state which indicates the employee's relationship with the organization, closely related to the decision to become a member of the organization, an individual's promise to the organization, including a sense of commitment with work, loyalty, and faith in the values of the organization. The authors also design scales "Commitment with the organization" including 18 indicators: (i) Affective Commitment (AC), refers to the closeness of the staff emotionally with organization; (ii) Normative Commitment (NC), based on a long relationship, which emphasizes the importance of the obligation and (iii) Continuance Commitment ( CC), which describes employees' perceptions of the damage when leaving an organization.

Studies in Vietnam on typical commitment such as: Research by Trinh \& Nguyen (2015) explained the commitment with the organization of knowledgable female workforce based on the situation of changing the workplace. The authors also said that one of the characteristics of commitment is the active participation of employees in the organization's activities and long-term attachment to the organization. Pham (2018), surveyed 560 lecturers from 10 universities and colleges in Hanoi, Thaibinh and Tuyenquang on the impact of awareness of school reputation on the commitment of lectures. The author affirms that the commitment is defined as the psychological attachment of the lecturer to the school, in which the lecturer works due to his true feelings, wishes, and desires to contribute to the development and growth of the school (emotional commitment) or due to the sense of responsibility that attaches to the school (responsibility commitment) or awareness of the benefits when working at school (linked needs interests commitment). Based on a study of Ko (1996), Bui (2017) conducted a survey of 250 bank employees in HoChiMinh City on the influence of leadership on employees' commitment in joint-stock commercial banks in HoChiMinh City. The results of the study show that the commitment with the organization of a bank employee consists of 13 attributes (indicators), of which the commitment based on emotion includes 4 indicators, the commitment based on benefits include 5 indicators and the commitment based on ethics including 4 indicators.

This study is one of the first studies in Vietnam on the commitment of accountants with organizations. We conduct research of the commitment with FDI firms of accountants because : At present, Vietnam's economy is integrating with the global economy, more and more foreign investors pour money into Vietnam, FDI firms in industrial zones still have difficulty in recruiting accounting positions as well as retaining accountants, Vietnam's accounting system is changing a lot when the Ministry of Finance has built and developed the roadmap of applying financial reporting standards internationally (IFRSs) in Vietnam.

\section{Research Methodology}

Research subjects: The research subjects of this study are accountants in the FDI firms in Noi Bai industrial park, Hanoi.

Qualitative research methodology: We used a qualitative research methodology based on some in-depth interviews with 3 lecturers with extensive experiences in accounting in FDI firms of the National Economics University and University of Labor and Social Affairs. They are the two leading universities in Vietnam in training accounting and human resource management. At the same time, we interviewed 3 experts working as chief accountants in FDI firms in Noi Bai industrial park. The contents of the interviews focus on the subject of the commitment of accountants's attributes.

Inheriting the results conducted by Meyer \& Allen (1991) and using qualitative research methodology through interviews with experts, we identify the commitment of accountants with FDI firms including 12 attributes in table 1 as follows, 
Table 1: Attributes of the commitment of accountants

\begin{tabular}{|c|c|c|}
\hline Code & Scale & Sources \\
\hline \multicolumn{3}{|c|}{ Affective Commitment (AC) } \\
\hline $\mathrm{AC} 1$ & I really found that I belong to this FDI firm & Mayer \& Allen (1991), results of expert interviews \\
\hline $\mathrm{AC2}$ & I have feelings for this FDI firm & Mayer \& Allen (1991), results of expert interviews \\
\hline $\mathrm{AC3}$ & I see this FDI firm as part of my family & Mayer \& Allen (1991), results of expert interviews \\
\hline $\mathrm{AC4}$ & This FDI firm means a lot to me & Mayer \& Allen (1991), results of expert interviews \\
\hline \multicolumn{3}{|c|}{ Normative Commitment (NC) } \\
\hline NC1 & $\begin{array}{l}\text { I feel obligated to maintain my job with the FDI } \\
\text { firm which I am working }\end{array}$ & Mayer \& Allen (1991), results of expert interviews \\
\hline $\mathrm{NC2}$ & This FDI firm deserves my loyalty & Mayer \& Allen (1991), results of expert interviews \\
\hline $\mathrm{NC3}$ & $\begin{array}{l}\text { I feel that I will still remain with FDI firms because } \\
\text { I feel I have a duty to everyone here }\end{array}$ & Mayer \& Allen (1991), results of expert interviews \\
\hline $\mathrm{NC4}$ & I owe this FDI firm for having a great working deal & Mayer \& Allen (1991), results of expert interviews \\
\hline \multicolumn{3}{|c|}{ Continuance Commitment (CC) } \\
\hline $\mathrm{CC} 1$ & $\begin{array}{l}\text { Although I really want to leave this FDI firm, I find } \\
\text { it really difficult }\end{array}$ & Mayer \& Allen (1991), results of expert interviews \\
\hline $\mathrm{CC} 2$ & $\begin{array}{l}\text { If I decide to leave FDI firms at this time, my life } \\
\text { will be in turmoil }\end{array}$ & Mayer \& Allen (1991), results of expert interviews \\
\hline $\mathrm{CC} 3$ & $\begin{array}{l}\text { I feel that I have too few options to consider leaving } \\
\text { this FDI firm }\end{array}$ & Mayer \& Allen (1991), results of expert interviews \\
\hline $\mathrm{CC} 4$ & $\begin{array}{l}\text { I made too much effort for this FDI firm so I will } \\
\text { stay }\end{array}$ & Mayer \& Allen (1991), results of expert interviews \\
\hline
\end{tabular}

Quantitative research methodology

We have designed a questionnaire consisting of 12 variables with a 5-point Likert scale from 1 "Strongly disagree" to 5 "Strongly agree". The method of data collection was accomplished through the survey and subjects were accountants doing in FDI firms in Noi Bai industrial park. We sent 150 questionnaires and received the feedback of 100 . Time to complete is one month. There were 110 questionnaires with full information for data entry and analysis, the size of this sample was consistent with study of Hair et al. (1988): The research sample must be at least 5 times the total number of indicators in the scales. The questionnaire of this study includes 12 indicators, therefore, the minimum sample size to achieve are $5 * 12=60$ observations.

After collecting 110 questionnaires, we cleaned the data and coded the necessary information in the questionnaires. We inputed the data and we used SPSS23 to analyze the data.

The steps of data analysis, as follows

(i) Descriptive statistics

(ii) Cronbach's Alpha: We assess the reliability of the scale

(iii) Independent T-test

\section{Research results}

\subsection{Descriptive Statistics}

Information of data collected is shown in Table 2

Table 2: Respondents by gender, age, job description, seniority work

\begin{tabular}{|c|c|c|c|}
\hline & Frequency & Percent & Cumulative Percent \\
\hline \multicolumn{4}{|l|}{ Gender } \\
\hline Male & 32 & 29.1 & 29.1 \\
\hline Female & 78 & 70.9 & 100.0 \\
\hline \multicolumn{4}{|l|}{ Age } \\
\hline Over 27 years old & 60 & 54.5 & 54.5 \\
\hline From 22 to 27 years old & 50 & 45.5 & 100.0 \\
\hline \multicolumn{4}{|l|}{ Job description } \\
\hline General accountants & 37 & 33.6 & 33.6 \\
\hline Chief accountants & 34 & 30.9 & 64.5 \\
\hline Accounting staff & 39 & 35.5 & 100.0 \\
\hline \multicolumn{4}{|l|}{ Seniority work } \\
\hline From 1 to 5 years & 71 & 64.5 & 64.5 \\
\hline Over 5 years & 39 & 35.5 & 100.0 \\
\hline Total & 110 & 100.0 & \\
\hline
\end{tabular}


Data in Table 2 show that among the 110 respondents, $29.1 \%$ of the participants were male while the remaining 78 were female, representing for $70.9 \%$. Of these, 50 of them from 22 to 27 years old, accounting for 45.5\%; and 54.5\% of the participants were over 27 years old. Among the 110 respondents, accounting staff accounted for $35.5 \%$, general accounting accounted for $33.6 \%$, while the remaining 34 were chief accountant, accounted for $30.9 \%$. Of these, $35.5 \%$ of the participants have from 1 to 5 years and over 5 years accounted for $64.5 \%$.

Table 3: Descriptive Analysis of Attributes of the commitment with FDI firms of accountants

\begin{tabular}{|c|c|c|c|c|c|}
\hline & $\mathrm{N}$ & Minimum & Maximum & Mean & Std. Deviation \\
\hline \multicolumn{6}{|c|}{ Affective commitment (AC) } \\
\hline $\mathrm{AC} 1$ & 110 & 2.0 & 5.0 & 3.527 & .775 \\
\hline $\mathrm{AC2}$ & 110 & 1.0 & 5.0 & 3.882 & .832 \\
\hline $\mathrm{AC} 3$ & 110 & 2.0 & 5.0 & 3.655 & .840 \\
\hline $\mathrm{AC4}$ & 110 & 2.0 & 5.0 & 3.673 & .692 \\
\hline $\begin{array}{l}\text { Valid N } \\
\text { (listwise) }\end{array}$ & 110 & & & 3.684 & \\
\hline \multicolumn{6}{|c|}{ Normative commitment (NC) } \\
\hline $\mathrm{NC} 1$ & 110 & 2.0 & 5.0 & 4.000 & .650 \\
\hline $\mathrm{NC2}$ & 110 & 2.0 & 5.0 & 4.009 & .748 \\
\hline NC3 & 110 & 2.0 & 5.0 & 4.045 & .759 \\
\hline $\mathrm{NC4}$ & 110 & 2.0 & 5.0 & 4.109 & .805 \\
\hline $\begin{array}{l}\text { Valid N } \\
\text { (listwise) }\end{array}$ & 110 & & & 4.041 & \\
\hline \multicolumn{6}{|c|}{ Continuance commitment (CC) } \\
\hline $\mathrm{CC} 1$ & 110 & 2.0 & 5.0 & 4.009 & .748 \\
\hline $\mathrm{CC} 2$ & 110 & 2.0 & 5.0 & 3.973 & .723 \\
\hline $\mathrm{CC} 3$ & 110 & 2.0 & 5.0 & 4.000 & .717 \\
\hline $\mathrm{CC} 4$ & 110 & 2.0 & 5.0 & 4.055 & .764 \\
\hline $\begin{array}{l}\text { Valid N } \\
\text { (listwise) }\end{array}$ & 110 & & & 4.009 & \\
\hline
\end{tabular}

Data in Table 3 illustrate that the respondents agree with the dependent variables of "the commitment with FDI firms of accountants" where 12 attributes were quite high with, inside (i) Affective commitment (AC) with an average of 3.684 compared with the highest of the Likert 5-point scale, all 4 attributes were rated at an average of 3.527 or higher. (ii) Normative commitment (NC) with an average of 4.041 compared with the highest of the Likert 5-point scale, all 4 attributes were rated at an average of 4.000 or higher. (iii) Continuance commitment (CC) with an average of 4.009 compared with the highest of the Likert 5-point scale, all 4 attributes were rated at an average of 3.973 or higher

\subsection{Cronbach's Alpha}

The commitment with FDI firms of accountants has been measured by the Cronbach's Alpha. Results of testing Cronbach's alpha of attributes are presented in Table 4 as follows, 
Table 4: Results of Cronbach's Alpha Testing of Attributes

\begin{tabular}{|c|c|c|c|c|}
\hline & $\begin{array}{l}\text { Scale Mean if } \\
\text { Item Deleted }\end{array}$ & $\begin{array}{l}\text { Scale Variance if } \\
\text { Item Deleted }\end{array}$ & $\begin{array}{l}\text { Corrected Item- } \\
\text { Total Correlation }\end{array}$ & $\begin{array}{l}\text { Cronbach's Alpha } \\
\text { if Item Deleted }\end{array}$ \\
\hline \multicolumn{5}{|c|}{$\begin{array}{l}\text { Affective commitment (AC): Cronbach's Alpha: .805 } \\
\text { N of Items: } 4\end{array}$} \\
\hline $\mathrm{AC} 1$ & 11.21 & 3.947 & .554 & .787 \\
\hline $\mathrm{AC} 2$ & 10.85 & 3.557 & .638 & .747 \\
\hline $\mathrm{AC} 3$ & 11.08 & 3.489 & .656 & .738 \\
\hline $\mathrm{AC4}$ & 11.06 & 3.987 & .646 & .748 \\
\hline \multicolumn{5}{|c|}{$\begin{aligned} \text { Normative commitment (NC): Cronbach's Alpha: .772 } \\
\text { N of Items: } 4 \\
\end{aligned}$} \\
\hline $\mathrm{NC1}$ & 12.16 & 3.367 & .608 & .705 \\
\hline NC2 & 12.15 & 2.994 & .651 & .675 \\
\hline NC3 & 12.12 & 3.316 & .487 & .763 \\
\hline $\mathrm{NC4}$ & 12.05 & 3.006 & .567 & .723 \\
\hline \multicolumn{5}{|c|}{$\begin{array}{r}\text { Continuance commitment (CC): Cronbach's Alpha: .810 } \\
\text { N of Items: } 4\end{array}$} \\
\hline $\mathrm{CC} 1$ & 12.03 & 3.219 & .663 & .745 \\
\hline $\mathrm{CC} 2$ & 12.06 & 3.326 & .649 & .753 \\
\hline CC3 & 12.04 & 3.320 & .660 & .747 \\
\hline $\mathrm{CC} 4$ & 11.98 & 3.431 & .545 & .802 \\
\hline
\end{tabular}

The results also show that attributes of the dependent variables had a Cronbach's Alpha coefficient greater than 0.6; the correlation coefficient of all attributes was greater than 0.3 , so all the attributes of the dependent variables were statistically significant (Hoang \& Chu, 2008).

\subsection{Independent $\mathbf{T}$ - test}

Comparing the results of the evaluation of the commitment with FDI firms of accountants between participants are difference about seniority work (from 1 to 5 years and over 5 years) is shown in Table 5, table 6 and table 7 .

Table 5: Differences of the Affective commitment (AC) of accountants between participants are different about seniority work - Independent Test

\begin{tabular}{|c|c|c|c|c|c|c|c|c|c|c|}
\hline & \multicolumn{2}{|c|}{$\begin{array}{c}\text { Levene's Test } \\
\text { for Equality of } \\
\text { Variances }\end{array}$} & \multicolumn{7}{|c|}{ t-test for Equality of Means } \\
\hline & & \multirow[b]{2}{*}{$\mathrm{F}$} & \multirow[b]{2}{*}{ Sig. } & \multirow[b]{2}{*}{$\mathrm{t}$} & \multirow[b]{2}{*}{$\mathrm{df}$} & \multirow{2}{*}{$\begin{array}{l}\text { Sig. } \\
(2- \\
\text { taile } \\
\text { d) }\end{array}$} & \multirow{2}{*}{$\begin{array}{c}\text { Mean } \\
\text { Differenc } \\
\mathrm{e} \\
\end{array}$} & \multirow{2}{*}{$\begin{array}{c}\text { Std. } \\
\text { Error } \\
\text { Differenc } \\
\mathrm{e} \\
\end{array}$} & \multicolumn{2}{|c|}{$\begin{array}{l}95 \% \text { Confidence } \\
\text { Interval of the } \\
\text { Difference }\end{array}$} \\
\hline & & & & & & & & & Lower & Upper \\
\hline \multirow[t]{2}{*}{$\mathrm{AC}$} & $\begin{array}{l}\text { Equal } \\
\text { variances } \\
\text { assumed }\end{array}$ & 1.981 & .162 & -.773 & 108 & .441 & -.09651 & .12481 & -.34391 & .15088 \\
\hline & $\begin{array}{l}\text { Equal } \\
\text { variances } \\
\text { not assumed }\end{array}$ & & & -.732 & 66.813 & .467 & -.09651 & .13188 & -.35977 & .16674 \\
\hline
\end{tabular}

According to the results of Table 5, Sig Levene's Test $=0.162$ more than 0.05 ; the variance between the two from 1 to 5 years and over 5 years is not different. Moreover, Sig value T-Test $=0.441>0.05$, which means there is not statistically significant difference in the level of the Affective commitment (AC) of accountants competence evaluation by workers who have different seniority work (Hoang \& Chu, 2008). 
Table 6: Differences of the Normative commitment (NC) of accountants between participants are different about seniority work - Independent Test

\begin{tabular}{|c|c|c|c|c|c|c|c|c|c|c|}
\hline & \multicolumn{2}{|c|}{$\begin{array}{l}\text { Levene's Test } \\
\text { for Equality of } \\
\text { Variances }\end{array}$} & \multicolumn{7}{|c|}{ t-test for Equality of Means } \\
\hline & & \multirow[b]{2}{*}{$\mathrm{F}$} & \multirow[b]{2}{*}{ Sig. } & \multirow[b]{2}{*}{$\mathrm{t}$} & \multirow[b]{2}{*}{$\mathrm{df}$} & \multirow{2}{*}{$\begin{array}{l}\text { Sig. } \\
(2- \\
\text { taile } \\
\text { d) }\end{array}$} & \multirow{2}{*}{$\begin{array}{c}\text { Mean } \\
\text { Differenc } \\
\mathrm{e} \\
\end{array}$} & \multirow{2}{*}{$\begin{array}{c}\text { Std. } \\
\text { Error } \\
\text { Differenc } \\
\text { e } \\
\end{array}$} & \multicolumn{2}{|c|}{$\begin{array}{l}95 \% \text { Confidence } \\
\text { Interval of the } \\
\text { Difference }\end{array}$} \\
\hline & & & & & & & & & Lower & Upper \\
\hline \multirow[t]{2}{*}{$\mathrm{NC}$} & $\begin{array}{l}\text { Equal } \\
\text { variances } \\
\text { assumed }\end{array}$ & 2.368 & .127 & -1.079 & 108 & .283 & -.12297 & .11397 & -.34887 & .10293 \\
\hline & $\begin{array}{l}\text { Equal } \\
\text { variances } \\
\text { not assumed }\end{array}$ & & & -1.018 & 66.207 & .312 & -.12297 & .12081 & -.36416 & .11822 \\
\hline
\end{tabular}

According to the results of Table 6, Sig Levene's Test $=0.127$ more than 0.05 ; the variance between the two from 1 to 5 years and over 5 years is not different. Moreover, Sig value T-Test $=0.283>0.05$, which means there is not statistically significant difference in the level of the Normative commitment (NC) of accountants competence evaluation by workers who have different seniority work (Hoang \& Chu, 2008).

Table 7: Differences of the Continuance commitment (CC) of accountants between participants are different about seniority work - Independent Test

\begin{tabular}{|c|c|c|c|c|c|c|c|c|c|c|}
\hline & \multicolumn{2}{|c|}{$\begin{array}{c}\text { Levene's Test } \\
\text { for Equality of } \\
\text { Variances }\end{array}$} & \multicolumn{7}{|c|}{ t-test for Equality of Means } \\
\hline & & \multirow[b]{2}{*}{$\mathrm{F}$} & \multirow[b]{2}{*}{ Sig. } & \multirow[b]{2}{*}{$\mathrm{t}$} & \multirow[b]{2}{*}{ df } & \multirow{2}{*}{$\begin{array}{l}\text { Sig. } \\
(2- \\
\text { taile } \\
\text { d) }\end{array}$} & \multirow{2}{*}{$\begin{array}{c}\text { Mean } \\
\text { Differenc } \\
\mathrm{e} \\
\end{array}$} & \multirow{2}{*}{$\begin{array}{c}\text { Std. } \\
\text { Error } \\
\text { Differenc } \\
\text { e }\end{array}$} & \multicolumn{2}{|c|}{$\begin{array}{c}95 \% \text { Confidence } \\
\text { Interval of the } \\
\text { Difference }\end{array}$} \\
\hline & & & & & & & & & Lower & Upper \\
\hline \multirow[t]{2}{*}{$\mathrm{CC}$} & $\begin{array}{l}\text { Equal } \\
\text { variances } \\
\text { assumed } \\
\end{array}$ & .001 & .970 & -.880 & 108 & .381 & -.10347 & .11760 & -.33656 & .12963 \\
\hline & $\begin{array}{l}\text { Equal } \\
\text { variances } \\
\text { not assumed }\end{array}$ & & & -.873 & 76.630 & .385 & -.10347 & .11851 & -.33947 & .13253 \\
\hline
\end{tabular}

According to the results of Table 7, Sig Levene's Test $=0.970$ more than 0.05 ; the variance between the two from 1 to 5 years and over 5 years is not different. Moreover, Sig value T-Test $=0.381>0.05$, which means there is not statistically significant difference in the level of the Continuance commitment (CC) of accountants competence evaluation by workers who have different seniority work (Hoang \& Chu, 2008).

\section{Conclusion and administration implications}

\section{Conclusion}

The accounting department is one of the most important departments in firms: (i) Providing firms with the numbers in the business, (ii) Balancing the costs to make the highest profit, (iii) Providing accounting information through the accounting system and (iv) Contributing to attracting investment. Therefore, it is becoming more important to retain good accountants staying with FDI firms. The stability of the accounting staff will help FDI firms save costs, limit possible errors, create a trust for workers in recruiting and using accounting workers.

We used the qualitative and quantitative research methods, processed data by statistical method to define 12 attributes of the dependent variable.

\section{Administration implication}

The commitment with FDI firms of accountants directly influences on the development of FDI firms: The numbers of accountants being absence and quitting jobs is lower, labor productivity is higher, the connection between accountants and with employees of FDI firms is increasing.

The working environment in FDI firms also appears rumors which stem from some reasons. Hence, leaders need to address all concerns of employees in the working environment by exchanging, discussing with employees and listening to their shares, wishes, aspirations or questions. Leaders publicly comment and 
respond to employees' concerns in the most honest way so as to break employee's doubts and make them feel fully deserved and respected. Meanwhile, all employees' worries are answered directly and they also understand that this working environment really associates personnel.

The above research results show that accountants do not really understand the importance of their work (Continuance commitment). Consequently, the leaders should give justified arguments to show employees that the work they are doing is important for businesses and for themselves. For businesses, the absence of employees will make the business become stagnant, even stop operating. For employees, this is an environment that helps them connect, grow and learn from each other, helping each other improve gradually. From that point, the employees will feel love the work they are doing and feel satisfied because their contributions are meaningful to the business.

Characteristics of accounting require accountants to both works independently and teamwork. However, it is a shortcoming if the environment in FDI firms focuses too much on teamwork, but ignoring the individual's independent capabilities because every accountant has a different ability to think and create particular ideas. Therefore, the leaders need to listen to all employees, assess and select opinions fairly.

Employees in general, accountants in particular, before deciding to start or continue a job at a certain business, they are all very concerned about the welfare of that company. In consequence, in order to develop human resources, increase employees' commitment with businesses and create the highest profit, the leaders should invest in employees' welfare such as annual social insurance, holiday gifts, organizing interesting orientation for new employees, business theme days, paid leave, expanding workspace, reducing pressure programs, etc.

\section{References}

1. Alexander JA, Bloom J R \& Nichols B A. (1994), 'Nursing Turnover \& Hospital efficiency: an Organizational level analysis', Industrial Relations, Vol 33, 505-520.

2. Bui, T.P.L (2017), The influence of leadership styles on emplyees' engagement at HoChiMinh City-based commercial banks, Economy and Forecasi Review, No 36, 39-42.

3. Dess, G.D \& Shaw, J.D. (2001), 'Voluntary Turnover - social capital and organizational performance', Academy of Management Review. Vol 26 (3), 446-456.

4. Hair, J., Anderson, R., Tatham, R., \& Black, W., (1998), Multivariate Data Analysis with Readings (5th Ed.). Prentice- Hall International, Inc. United States.

5. Hoang, T., \& Chu, N.M.N (2008), Analysis of research data with SPSS. Hong Duc Publishing House.

6. Ko, J.W., (1996). Assessment of Meyer and Allen's three component model of organizational commitment in South Korea (Jame L. Price (1997). Handbook of organizational measurement, Internation Joumal Manpowe, 305-558).

7. Meyer, J. P. \& Allen, N. J., (1991), 'A three-component conceptualization of organizational commitment', Human Resource Management Review, 1: 61.

8. Mowday, R., Steers, R., \&. Porter, L. (1979), The measurement of organizational commitment, Journal of vocational Behavior, 14, 224-227.

9. O'Reilly, C. A., \& Chatman. J., (1986). Organization eommitment and psychological attachment the effects of compliance, identification and internalization on prosocial behavior, Joumal of applied psychology, 71, 492-499.

10. Osterman, (1987), 'Choice of Employment Systems in Internal Labor Markets. Industrial Relations', A Journal of Economy and Society, Volume 26, Issue 1, 46-67.

11. Pham, T.H.P. (2018), The impact of awareness of school reputation on faculty alignment, Psychological journal, No 1 (226), 79-89.

12. Ramsey, S.G., (2004), 'Employee Turnover - The real cost', Strategic HR Review,Vol 3 No4, 7.

13. Smith, J.J. (2007), China faces talent paradox, high employee turnover. Society for Human Resource Management Headline News.

14. Trinh, T.L \& Nguyen, T.V.T. (2015), Commitment with the organization of female knowledge viewed from a number of demographic factors, Psychological journal, No 11 (200), 86-99. 